\title{
Utilizing Political Ideologies To Market A Political Candidate
}

Shermichael V. Singleton, Morehouse College, USA

Andrew Honeycutt, Shorter University, USA

\begin{abstract}
This article explores the reductionist approach of political ideologies as used by political candidates, which is part of the common feature of political marketing. Understanding the value or belief system which is accepted as fact or truth by the targeted group, places the candidate in a position to promote them self as a well-intentioned, committed leader who seeks to motivate the audience to action. Modern marketing of political candidates begins by understanding central concepts of ideologies. The utilization of ideologies is complex, in that there is no single concept or claim revealing surprising affinities with various images of the candidate. It also has distinctive function, by misrepresenting the totality of the ideology by forming a total belief in the candidate versus the ideology in a particular way. People must commit or surrender to the demands of the candidate, thus making it possible for the candidate to get elected. The branding of the candidate while utilizing political ideologies in part disables people from easily disregarding information perceived to be antithetical to the concepts of the ideology (Quelch, 2007).
\end{abstract}

Keywords: Political Ideology; Marketing Political Candidate

\section{INTRODUCTION}

$\mathrm{n}$ analyzing the electoral market Adrian Sackman emphasizes the point: "Marketing is thus built upon a paradox; it starts with the customer, is directed at the customer, but is fundamentally concerned with the satisfaction of the producer's own interests" (Sackman 1992). Political ideologies encompasses every aspect of our belief system and are most critical in our decision making process. We base our decisions off of our ideals, how we view the world, its worldly structures and society. The ideology provides us with a picture of the world in two ways: as it is and as it should be. Politicians and candidates alike, knowingly or unknowingly, utilize ideologies to market themselves. They do this in part by organizing the complete complexities of the world into something fairly simple and understandable. By properly marketing themselves they are able to secure support, which turns into votes by utilizing marketing outfitted with the power of complex convictions.

\section{Defining Political Marketing}

Kotler and Levy (1969) argued that elections should be one of the new arenas of marketing interest: "Political contests remind us that candidates are marketed as well as soap." However the first recorded use of the term "political marketing" did not appear in a formal study until political scientist Stanley Kelley charted the emergence of the professional campaign industry in the United States.

Commenting on the activities of the first election consultancies, Kelley wrote: "The team relies heavily but not entirely upon their own intuitive feel for providing political marketing conditions. They pride themselves on having "good average minds" that help them to see things as the average man sees them." (Kelley 1956)

Marketing purists, whose sympathies with the "broadening thesis" began to attempt to elucidate, refine and establish the sub-field of political marketing. By the mid-1970s American scholars such as Avraham Shama (1974; 1976) and the prolific Philip Kotler (1975) were at the forefront of developing theoretical foundations for the subject. Similarly experts in Europe began to consider the political dimension to marketing, positing the view that 
an exchange relationship existed between democratic elites and their voters (O'Leary and Iredale 1976). By the mid1980s a steady stream of research discussing the emergence of the phenomenon helped confirm its importance (Mauser 1983; Newman and Sheth 1985). Writing in 1988 David Reid concluded that: "In western terms, although seldom recognized by politicians, the problem of getting elected is essentially a marketing one. Political parties must determine the scope and the most effective way of communicating its benefits to a target audience." (Reid 1988)

\section{Political Campaigns and Marketing}

Political campaigns have increasingly been compared to marketing campaigns in which the candidate puts himself in the vote market and uses modern marketing techniques, particularly marketing research and commercial advertising, to maximize voter "purchase." The marketing analogy is more than coincidental. It is argued here that the very essence of a candidate's interface with the voters is a marketing one, not only in recent times but far back into the past. Candidates seeking to win elections cannot avoid marketing themselves. The only question is how to do it effectively and responsibly (Kotler 1975).

Each candidate develops a product concept that he believes is merchandisable to voters. This concept is built upon a mixture of political ideology which stands upon particular issues, personal style, and background qualifications. Each candidate seeks to reach the voters through three major distribution channels: mass and selective media, personal appearances, and volunteer and party workers. Candidates mobilize voters by understanding their values and beliefs and by using that understanding of ideological concepts. These channels interact, e.g., a personal appearance reaches an immediate physically present audience and also a larger audience through mass media coverage. These efforts are adjusted for different voter segments, and the results are continuously reviewed for further campaign modification (Keller 2009). The candidate must market themselves around many issues, revealing affinities with various images.

\section{Marketing and Political Ideology}

Marketing is about identifying and meeting human and social needs (Kotler 2007). There are many mitigating forces that encourage an idea which externally gets a person to participate in political elections. At its core, political ideologies offer a sense of identity to its followers.

It would be a mistake to think the utilization of political ideologies to market a political candidate is new methodology which has taken on in recent years. The "new methodology" is not the introduction of utilizing political ideology to market a candidate but rather an increased sophistication and acceleration of its use.

We may identify ourselves through one of the ideological traditions as liberal, conservative, socialist, feminist, fascist or other (Festenstein and Kenny, 2005). By understanding the values or beliefs systems voters accept, candidates proudly announce their ideological convictions. Focusing on the latter, candidates are able to understand the needs and aspirations of consumers or citizens, and develop products or policy propositions in response (Quelch 2008).

Voters are more likely to suspend their own criticisms, questions, or concerns about the veracity of the candidate (Manheim 1936), if complex ideologies are turned into simple concepts. Turning complexities of ideologies into simplistic entities are a common theme in politics.

The method contains discursive and non-discursive elements. This distinction between discursive and nondiscursive elements is the same as the distinction made by Raymond Guess. 'Discursive' (or 'conceptual' or 'propositional') elements, includes concepts, ideas, and beliefs, while 'non-discursive' elements encompass characteristics, gestures, attitudes, etc (Guess 1981).

The successful marketable candidate utilizes ideology to position them self as well-intentioned, committed leaders by understanding the systems of ideology or values or beliefs, by triggering an emotional response from voters and by projecting analysis of social problems and issues of relevance to the electorate. 
The "new methodology" marketing of a political candidate begins by understanding central concepts of ideology. Since there is no single concept of ideology, it takes on a heterogeneous range of guises. What determines the specific content that one gives to an issue such as poverty or war, of course, depends on the interpretation of such issues on the part of those who hold them such as a liberal or conservative. In part this dictates how candidates "project" themselves to voters and economic, social, education and other issues of importance.

\section{The Political Marketing Process Utilizing Political Ideology}

The political marketing process as outlined in Table 1 consists of four parts; the chameleonic candidate, the environment which conditions its development, the strategic mix of issues deployed, and the market in which it must operate.

Adopting the maxim of Schumpeter (1943) that democracy is primarily concerned with parties' "competitive struggle for (the) people's vote", Gamble contends that, "The main components of the modern political market are three; the existence of a mass electorate; competition between two or more parties for the votes of this electorate; and a set of rules governing this competition." (Gamble 1974)

Within the political market the key relationship is based on a concept central to marketing theory, namely that of exchange between buyer and seller. Thus citizens give their votes to politicians who, when elected, purport to govern in the public interest (Scott 1970; Lane 1993). In a modern democracy the right to vote, commonly associated with the age of majority, allows for a mass electorate which can typically number well into the millions.

\section{Table 1: Political Marketing Utilizing Political Ideology}

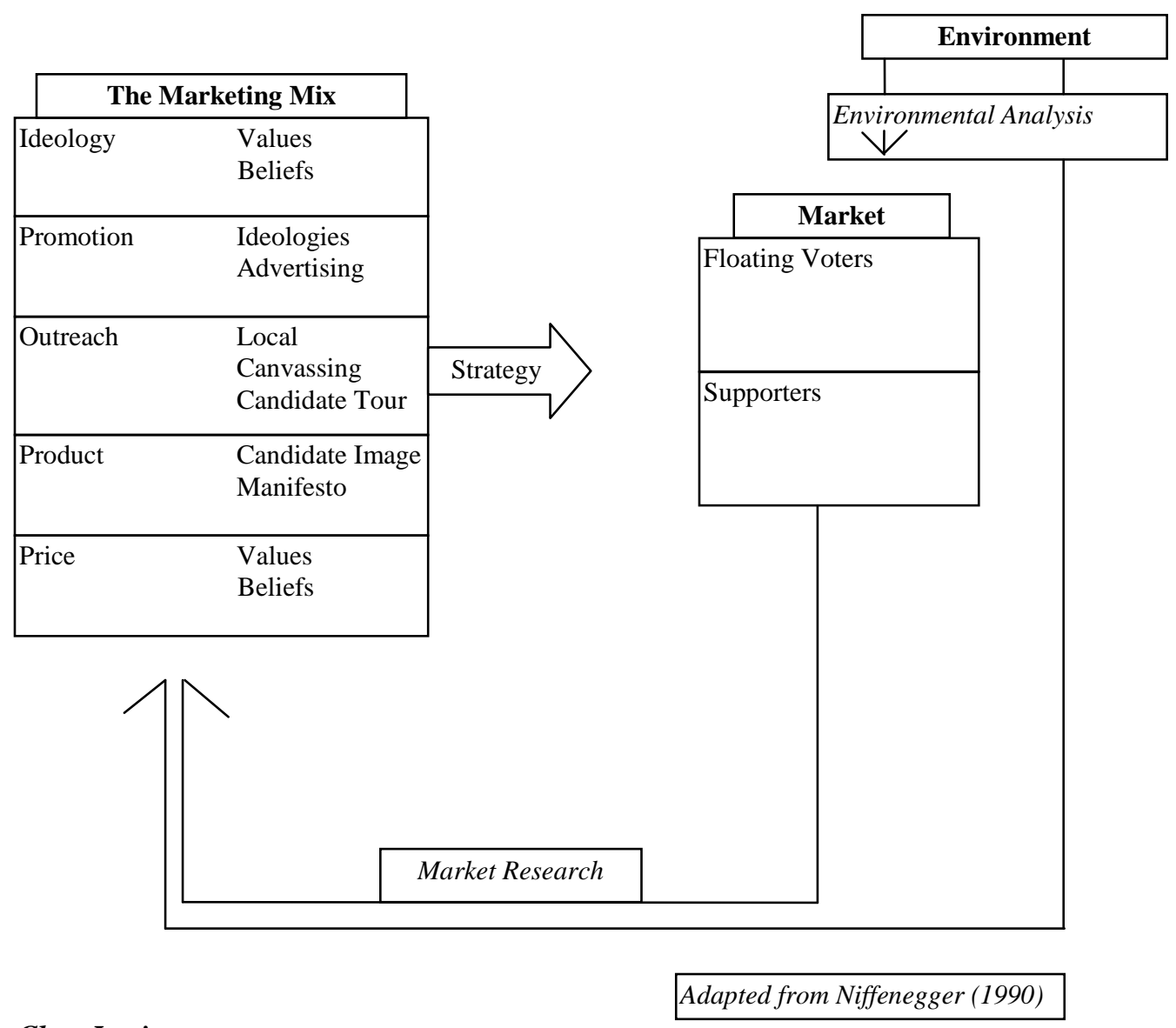


The diagram above shows the interrelational relevance of the concept of political marketing. It utilizes political ideology justified through this outlining. Relevance of this by outlining its constituent parts. These elements, relating to environmental phenomena as interpreted by the electorate, comprise voter values or beliefs. The notion of the political "price" reflects Reid's observation that a vote is a "psychological purchase" (Reid 1988). Although parallels between electoral consumer behaviour have been more comprehensively analysed by Lane (1993), the above chart elucidates the essentials.

\section{CONCLUSION}

Ideologies have an expressive dimension, offering a sense of identity to individuals and groups. Ideological commitments provide a sense of where a person belongs, how he or she relates to others, and who their friends and enemies are, political and non-political (Festenstein and Kenny, 2005). In this respect, candidates can dispatch specific promises to voters in exchange for their votes. By understanding the concepts of ideology, candidates can communicate to convey their mind influencing promises.

Candidates market in a way that indicates that they are unwavering proponents of the ideology. Through communication, emotional appeal, baby kissing and speechmaking, voters more easily disregard information perceived to be antithetical to the candidate. They are willing to suspend their own criticisms, questions, or concerns about the veracity of the candidate in the name of the ideology because the candidate organizes the complexities of the world into understandable simplicity fairly simple and understandable. By doing so, the candidate is able to create a successful marketing machine.

Marketing is about understanding the needs and aspirations of citizen consumers, and about developing acceptable products or policy propositions in response. By utilizing political ideologies, political candidates use a reductionist approach on issues relevant to the voter based on their ideology.

The political aspirant must have a good understanding of his market's needs, perceptions, and preferences. He must be guided by reliable and valid models of consumer behaviour (Kotler 1975).

The reality that politicians are increasingly using appeals based on the promotion of image, at the expense of issues and ideology has become a common feature. However such a view can no longer be regarded as a cliché and commands significant academic support (Biocca 1991; Franklin 1994). The marketing of politics means the reduction of ideology to marketable images.

\section{ACKNOWLEDGEMENT}

I would like to acknowledge and give special thanks to Dr. Andrew Honeycutt for advising me throughout the course of my research. His expertise in marketing, gave me great insight and direction.

\section{AUTHOR INFORMATION}

Shermichael Singleton is CEO of Singleton Strategies a political consulting firm. Mr. Singleton is a candidate for a Bachelors of Arts degree in Political Science with a concentration in Political Theory at Morehouse College. He is the author of numerous political OP:ED journals ranging from politics, political ideology, business and the economy. He has consulted across the country for various political candidates, on the local, state and federal levels. He has had various positions including but not limited to, deputy campaign manager, strategist and field organizer. His skills in the electoral context and his ability to understand the issues affecting various communities and create a successful message for a successful campaign are unyielding. E-mail: shermichaelsingleton@ yahoo.com.

Dr. Andrew E. Honeycutt is the recipient of the Doctor of Business Administration degree in Marketing from Harvard University and the Masters in Business Administration degree from Boston University. He is also a Northwestern University Nissan Marketing Fellow. Andrew currently is the Distinguished Fellow of Business of Shorter College, Rome, Georgia. E-mail: ahoneyc151@aol.com. 


\section{REFERENCES}

1. Biocca, F. (Ed), (1991), Television and Political Advertising: Volume 1, Psychological Processes, New York, Lawrence Erlbaum.

2. $\quad$ Dominic Wring, Dominic. "Reconciling Marketing with Political Science: Theories of Political Marketing." Journal of Marketing Management 13 (1997): 653-61. Print.

3. Festenstein, Matthew, and Michael Kenny. Introduction. Political Ideologies: a Reader and Guide. Oxford: Oxford UP, 2005. Print.

4. Franklin, R. (1994), Packaging Politics: Political Communications in Britain's Media Democracy, London, Edward Arnold.

5. $\quad$ Keller, K. L. \& Kolter, P. (2009). Marketing Management: Upper Saddle River, NJ: Pearson Prentice Hall

6. Kotler, P. and Levy, S.J. (1969), "Broadening the Concept of Marketing”, Journal of Marketing, 33, pp. $10-15$.

7. $\quad$ Kotler, Philip. "Overview of Political Candidate Marketing." Advances in Consumer Research 02: 761-70.

8. $\quad$ Kotler, Philip. Marketing Management. Upper Saddle River, NJ: Prentice Hall, 2003. Print.

9. Lane, R. (1993), "Voting and Buying: Political Economy on the Small Stage", paper presented at the Annual Meeting of the Society for the Advancement of Socio-economics, New York School for Social Research, New York, March.

10. Levitt, Theodore, "Marketing Myopia", Harvard Business Review, 1960

11. Niffenegger, P. (1989), "Strategies for success from the political marketers", Journal of Consumer Marketing, 6, pp. 45-51.

12. Qualter, T. (1985), Opinion Control in the Democracies, Hampshire, Macmillan.

13. Quelch, John A., and Katherine E. Jocz. Greater Good: How Good Marketing Makes for Better Democracy. Boston, MA: Harvard Business, 2007. Print.

14. Sackman, A.(1992), "The Marketing Organisation Model: Making Sense of Modern Campaigning in Britain", paper presented at the UK Political Studies Association Annual Conference, Belfast, April.

15. Scott, A.M. (1970), Competition in American Politics, New York, Holt, Rinehart and Winston.

16. $\quad$ Wring, Dominic. "Reconciling Mrketing with Political Science: Theories of Political Marketing." Journal of Marketing Management 13 (1997): 651-63. Print. 


\section{NOTES}

